\title{
A DISCOURSE ANALYSIS OF FIGURATIVE LANGUAGE IN BARRACK H. OBAMA'S SPEECH
}

\author{
Lestary Sudarsono, Nurmin Samola, Mister Gidion Maru
}

\begin{abstract}
Language is fundamental to all social processes, and human do need language to communicate to each other. In social process, there are people who communicate more than they say, they use language that indicate meanings more than the language does. This term is called figurative language. By conducting the study about language in use, we undertake a discourse analysis. In this research, a discourse analysis is conducted in Barrack Obama's first inaugural address with point of view of four types figurative language, they are metaphor, personification, paradox, and hyperbole. The purpose of this research are to find out four types of figurative language and interpret the meanings indicate in that figurative expressions. In conducting this research, descriptive qualitative method was used. The results of this research were described qualitatively from the stage categorization of the figurative language until explanation and interpretation of the figurative expressions. The analyzing of this research was supported by the related references to this research. By analyzing the data based on the related theory, the result of this research showed that there are 52 figurative expressions, where metaphor had the highest frequency as 24 expressions or $46.15 \%$, followed by hyperbole as 14 expressions or $26.92 \%$, expressions of personification as 9 expressions or $17.30 \%$, and the least frequency is paradox as 5 expressions or $9.61 \%$. From those result could be concluded that in Obama's speech contained huge number of figurative expressions. This fact showed that figurative language is important and could influence the language to become more powerful and more artistic.
\end{abstract}

Keyword: Figurative Language, Discourse Analysis, Speech, Obama

\section{INTRODUCTION}

In order to use language to communicate to each other, people include a meaning in their language, although sometimes there are language that have no meanings or meaningless. It occurs when their words are representing nothing. In other hand, there are also words that not representing the real meaning of the words. It is like when we say something beside the ordinary way of saying it. In linguistics, this term is called figurative language.

Figurative language is language using figures of speech - is language that cannot be taken literally (or should not be taken literally only) (Laurence Perrine, 1963). Figurative 
language has several types that have been used in literary works, but this research only focused on four types of figurative language, which are metaphor, personification, paradox and hyperbole. To analyze those types of figurative language, speech has been chosen as the object of this research.

In conducting a good speech, people usually use figurative languages to persuade and influence the audience. By using figurative language, the statement in the speech would be more powerful, interesting and attractive. At this point, it is clear that language has a power in society.

Inaugural Addresses of American's President is a kind of speech chosen as the object of this research, particularly the first inaugural address of Barrack H. Obama. This discourse analysis research was conducted of the analyzing the inaugural address of Obama seen from the figurative language used in the speech. Based on the previous explanations, in literary works for instance speech, consists of language that not consider on grammatical rules only, but also the good diction and figurative language that contain the huge influence and deep meaning as the specification. From that point, this research intended to study about the language used in Obama's speech, with the point of view of figurative language. This study is grounded on the attempt to anwer the following question; What are the types of figurative language used in the inaugural address of Barrack H. Obama?, and What do the figurative languages used in the address indicate?

Perrine (1963) defined figures of speech as a way of saying one thing and meaning another. She also stated that figurative language is language using figures of speech - language that cannot be taken literally (or should not be taken literally only). In this research, the kinds of figurative language that divided by Perrine is used, but the kinds have been eliminated only into four types of figurative languages, they are metaphor, personification, paradox and hyperbole.

- Metaphor

Metaphor is a variety of analog which compare two things directly, but in short pattern (Gorys Keraf, 1984). Perrine (2012) also state that metaphor is the comparison is not expressed but it created when a figurative term is substituted or identified with the literal term.

\section{- Personification}

According to Perrine $(2012,76)$, personification consists of giving the attribute of a human being to an animal, an object, or a concept. This statement is supported by Laurie Rozakis (1995) that personification is the attribution of human characteristics and/or feelings to non - human organisms, inanimate objects, or abstract ideas. 
- $\quad$ Paradox

Kennedy (1983) defined paradox is apparent self-contradiction or deliberate inconsistency. A statement or situation containing apparently contradictory or incompatible elements, but on closer inspection may be true. Furthermore, paradox is an apparent contradiction that is nevertheless somehow true. It may be either situation or statement. As a figure of speech, paradox is a statement. (Laurence Perrine, 2012). She also stated "when we understand all the condition and circumstances involved in a paradox, we find that what at first seemed impossible is actually entirely plausible and not strange at all."

- Hyperbole

Hyperbole is simply exaggeration, but exaggeration in the service of truth (Laurence Perrine, 2012). Leech $(1969,168)$ assumed hyperbole is frequently concerned with personal values and sentiments; that is, with making subjective claims which, however exaggerated.

This research is a qualitative in method. The term qualitative research refers to research that is based on descriptive data that does not make (regular) use of statistics procedures (Mackey and Gass, 2005: 162). Furthermore, qualitative research entails collecting primarily textual data and examining it using interpretive analysis (Heigham and Croker, 2009). The results of the analysis will be presented explained descriptively.

In conducting this research, documentation was chosen as the method of collecting data. Document is one of another data sources in qualitative research. This source have several advantages than the other. Document is a data naturalistic and easy to obtain (Setiadi, 2006). Furthermore, John Scott (2006) stated that documentary research involves the use of text and documents as source materials: governments publications, newspapers, certificates, census publications, novels, film and video, paintings, personal photographs, diaries and innumerable other written, visual and pictorial source in paper, electronic, or other 'hard copy' form. In this research, the formal document from governments publication, for instance the script of Barrack H. Obama's Inaugural addresses have been chosen.

In this research, discourse analysis was used as the method of analyzing data. Yule and Brown (1983) in Discourse Analysis defined the analysis of discourse is, necessarily, the analysis of language in use. The discourse analysis is committed to an investigation of what that language is used for. Moreover from Yule (2006), he said:

We were, in effect, asking how it is that language-users successfully interpret what other language-users intend to convey. When we carry this investigation further and ask how we make sense of what we read, how we can recognize well-constructed texts as opposed to those that are jumbled or incoherent, how we understand 
speakers who communicate more than they say, and how we successfully take part in that complex activity called conversation, we are undertaking what is known as Discourse Analysis.

The data collected were analyzed and categorized by referring to Perrine's namely personification, metaphor, hyperbole, and paradox. The types of figurative language that have been founded in the first and second address will be explained.

The result of analyzing the data as the answers of those questions was presented descriptively. The data categorized were presented and explained based on the types of the figurative language found.

There are 52 (fifty-two) expressions of figurative language were found in Obama's first inaugural address, but in this article there are only the brief of the result that were presented and explained.

\section{- $\quad$ Expressions of Metaphor}

\section{Rising tides of prosperity (Line 5)}

Explanation and meaning:

Rising tides in this expression refers to the up and down situation and prosperity refers to the economic state in America. The expression above substitute the description of the current economy of United State. Thus, this becomes metaphor since "the rising tides", which characterize the activity of up and down is directly compered to "prosperity", which is the economic rise. This figurative speech serves as vehicle to express the rise of people's welfare.

\section{The still waters of peace (Line 5)}

Explanation and meaning:

The still waters from the expression above describe the quiet moment in peace. This statement becomes a metaphor based on the comparison between the "still water" which is the quiet moment and "peace" which is the state of tranquility. This figure of speech is intend to express the peacefulness in American life.

\section{Amidst gathering clouds and raging storms (Line 6)}

Explanation and meaning:

This statement becomes the expression of metaphor since the "Gathering clouds and raging storms" compare to the crises and problems that America should face. This figurative statement is used to describe to the bad situations and bad times of America. 
4. These are the indicators of crisis, subject to data and statistics (Line 17) Explanation and meaning:

"These" in this sentence refers to the lines before which are "our economy is badly weakened, homes have been lost, jobs shed, businesses shuttered, our health care is too costly and our schools fail too many". The indicators of crisis in this sentence refers to the standard when the state of crisis occur. This statement becomes the expression of metaphor since the phenomenon of "these" which is the down stage of economy, business, health care and education is compared to "the indicators of crisis" which is the standard of warning status of American welfare. Thus, this figurative expression is a tool to express the crisis or warning stage of America could be observe based on those phenomenon.

\section{Their memories are short (Line 59)}

Explanation and meaning:

Short in this expression refers forgetfulness. This expression becomes a metaphor based on the comparison of "Their memories" and "short". This expression of figurative language describes that the enemies of America forget or cannot remember that America is a powerful country since the beginning. It could be seen from the history that have been carried by the early generation of America.

\section{- $\quad$ Expressions of Personification}

\section{Each day brings further evidence (Line 16)}

Explanation and meaning:

This statement becomes personification since "Brings" in this statement which is the human attribute that been used by the noun phrase "each day". This figurative speech describes that everyday shows the prove to the world.

2. The way we use energy strengthen our adversaries and threaten our planet

\section{(Line 16)}

Explanation and meaning:

The way we use energy is a concept that been given an attribute of human being which is strengthen and threaten. Thus, this statement becomes personification by the using of the human attribute above. This figurative statement means that the way of how American using their energy made their enemies stronger because it gave a disadvantage to America themselves in damaging their own country and this world. 
3. The challenges we face are real, they are serious and they are many (Line 19 and 20)

Explanation and meaning:

This expression becomes the expression of personification since the challenges in this statement is given the attribute of human which is serious. This figure of speech intends to describe that the challengers are surely want to damage the country.

\section{The state of the economy calls for action (Line 51)}

Explanation and meaning:

The economic situation of America was been giving the human attribute "calls", therefore this statement becomes the expression of personification. This figurative statement is indicated to express that the economic situation of America needs a help or we have to do something to improve it.

\section{Hungry minds (Line 98)}

Explanation and meaning:

"Hungry" is the concept that have been given the attribute of human, therefore this statement becomes the expression of personification. This figurative expression indicates that the minds need something fresh or something worth to think about.

\section{- $\quad$ Expressions of Paradox}

\section{Our health care is too costly (Line 14)}

Explanation and meaning:

America have a good health service and it really helps the citizen of America, but they cannot deny that there are still the poor people that cannot get the treatment because somehow they is not capable to pay for it, although it quiet reachable for the others. From the contradiction above, this statement becomes the expression of paradox. This figurative statement is a tool to express that the cost of the health service of America still cannot be reached by all the citizens.

\section{Our schools fail too many (Line 15)}

Explanation and meaning:

America education system is one of the best in the world, but it cannot be disproved that some of the school in America do not fulfilled the rights standards because of many aspects, such as the facilities, the students, and the teachers. Based on the contradiction that reveal above, this sentence becomes one of the expression of paradox. This figurative language is a tool to express the down of the education in America. 
3. We will begin to responsibility leave Iraq to its people, and forge a hardearned peace in Afghanistan (Line 82)

Explanation and meaning:

"Responsibility" in this statement, brings the contradiction of this statement. Therefore, this statement becomes paradox. Literally, America do not have the obligation to give the freedom for another country's citizens. But, as a huge and super power country, America is capable to deal the certain concern, therefore America assumed that they have the responsibility of that. This figure of speech is a vehicle to express the responsibilities of America as a huge country to expand peace to the world.

4. World grows smaller, our common humanity shall reveal itself (Line 92)

Explanation and meaning:

The expression of paradox in this statement comes from the contradiction which is the world is getting smaller, it is impossible, but in the other side, when the technologies improve so many, the world becomes easily, and people can access anything without many difficulties. This figure of speech intend to describe the effect of globalization.

5. Just as the fallen heroes who lie in Arlington whisper through the ages (Line 103)

Explanation and meaning:

"The fallen heroes" in this statement are the people who have passed away for forcing in sake of America. As the death people, they have been assumed cannot do anything anymore but in this statement they whisper through the ages, it is impossible but somehow it is true. From that contradiction above this statement becomes paradox expression. This figure of speech intends to describe that sacrifice of the death heroes of America will always give a history to be learned.

\section{- $\quad$ Expressions of Hyperbole}

\section{A nagging fear that America's decline is inevitable (Line 18)}

Explanation and meaning:

A nagging fear in this statement has been exaggerated to emphasize the fear of the bad situation of America. Therefore, this statement becomes a hyperbole. This expression of figurative speech describes that America cannot deny the fear of the current state in America. 
2. Reaffirm our enduring spirit (Line 26)

Explanation and meaning:

Enduring in this expression, exaggerated the spirit of America that is big and never end. Thus, this expression is one of the hyperbole. This figurative expression declare to keep the big and strong sprit of American citizen.

\section{Endured the lash of the whip (Line 37)}

Explanation and meaning:

"The lash of the whip" is the exaggeration of the hard work and hard time of the people of America who want to faith for their country. Thus, this statement becomes hyperbole, based on the exaggeration above. This figure of speech describes that those people no matter what keep receiving all of the grief for America.

\section{Struggled and sacrificed and worked till their hands were raw (Line 40)}

Explanation and meaning:

Struggled, sacrificed and worked till their hands were raw is the exaggeration, from that, this statement includes as a hyperbole. This figurative statement is indicated to the people who faith with free willingness to do everything for America, even work hard although it is harmful for them.

5. Without a watchful eye, the market can spin out of control, and that a nation cannot prosper long when it favors only the prosperous (Line 68)

Explanation and meaning:

This statement becomes a hyperbole based on the exaggeration of "the market can spin out of control". This figurative statement is intended to describe that without the awareness, the market can go practice the wrong way of business and America only help the prosperous people become richer.

\section{Conclusion}

After analyzing and presenting the figurative languages that could be found in Barack H. Obama First Inaugural Speech, in this chapter the conclusion of the results will be present. By analyzing the first inaugural address of Barack Obama, could be found that there are entirely 52 (fifty-two) expressions of figurative language in four types, which are metaphor, personification, paradox, and hyperbole. The first inaugural address of Barack Obama consists of 133 (one hundred and thirty-three) lines in eight pages, and contains many expressions of figurative languages. This fact shows that the use of figurative language in speech is important. Figurative languages influence the language to become more powerful and stronger the meanings. Therefore, figurative language brings a prove that language has the power to change people and even the world. 


\section{REFERENCES}

Heigham, J., \& Croker, R. A. (2009). Qualitative Research in Applied Linguistics: A Practical Introduction. London: Palgrave Macmillan.

Kennedy, X. J. (1983). Literature: An Introduction to Fiction, Poetry and Drama. NewYork: Longman Publishers, 1983

Keraf, G. (1984). Linguistik Bandingan Historis. Jakarta: Indonesia.

Leech, G. N. (1969). A Linguistic Guide to English Poetry. London and New York: Longman Group UK Limited.

Mackey, A., \& Gass, S. M. (2005). Second Language Research: Methodology and

Design. London: Laurence Erlbaum Associates, Publishers.

Perrine, L. (1963). Sound \& Sense: An Introduction to Poetry (2 ${ }^{\text {nd }}$ edition).

New York: Harcourt, Brace \& World, Inc.

Rozakis, L. (1995). How to Interpret Poetry. New York: A Simon \& Schuster Macmillan Company.

Scott, J. (2006). Documentary Research. United Kingdom: Sage Publishing, Ltd.

Setiadi, B. Ag. (2006). Metode Penelitian untuk Pengajaran Bahasa Asing:

Pendekatan Kuantitatif dan Kualitative. Yogyakarta: Graha Ilmu.

Yule, G. (2006). The Study of Language ( $3^{\text {rd }}$ edition). United States of America:

Cambridge University Press.

Yule, G., \& Brown, G. (1983). Discourse Analysis. United States of America:

Cambridge University Press.

http://obamaspeeches.com/. Accessed on October 24 2015. 